\title{
ATOM PROBE FIELD ION MICROSCOPY OF TITANIUM ALUMINIDES
}

\author{
D. J. Larson and M. K. Miller* \\ ${ }^{*}$ Metals and Ceramics Division, Oak Ridge National Laboratory, Oak Ridge, TN 37831-6376, USA
}

Titanium aluminides have a number of potential high temperature applications due to their good elevated-temperature mechanical properties, low density, and good creep and oxidation resistance. However, fabrication of commercial components of these materials has been impeded by their poor mechanical properties at ambient temperatures. Significant efforts with various degrees of success have been made to improve the mechanical properties of these TiAl alloys by doping them with a variety of different elements including $\mathrm{B}, \mathrm{C}, \mathrm{Cr}, \mathrm{Er}, \mathrm{Fe}, \mathrm{Mn}, \mathrm{Mo}, \mathrm{Ni}, \mathrm{Nb}, \mathrm{P}, \mathrm{Si}, \mathrm{Ta}, \mathrm{V}$ and W.' One of the optimum analytical tools for investigating the effects of these additions on the microstructure is the atom probe field ion microscope. ${ }^{2}$ However, relatively few studies of titanium aluminides, compared to some other intermetallic compounds, have performed by atom probe field ion microscopy. This lack of attention can be attributed to the brittle nature of the material, in-situ transformations that occur during the field ion microscopy and preferential evaporation problems that were encountered in some of the early studies. The atom probe field ion microscope used for the current experiments has a low base pressure $\left(\sim 2 \times 10^{-9} \mathrm{~Pa}\right)$ and careful attention was paid to optimizing the experimental parameters. All the examples shown were obtained from specimens prepared by standard electropolishing techniques. ${ }^{2}$

To demonstrate the suitability of the technique to these materials, several different titanium aluminides have been characterized in the atom probe. A field ion micrograph of a stoichiometric $\mathrm{Ti}_{3} \mathrm{Al}\left(\alpha_{2}\right)$ material is shown in Fig. 1. Many crystallographic poles and little indication of zone contrast are evident in this micrograph. A field ion micrograph of a higher aluminum level Ti-44 at. $\% \mathrm{Al}-0.4 \% \mathrm{~B}$ alloy that was processed to retain the $\alpha$ phase is shown in Fig. 2. Some zone contrast and a few bright spots, presumably due to the boron addition, are evident. In contrast, few crystallographic poles are evident in the field ion micrograph of a single $\alpha_{2}$-phase ternary Ti-20 at. $\% \mathrm{Al}-10 \% \mathrm{Zr}$ alloy shown in Fig. 3. Zone contrast is also evident in the $\gamma$ phase in a Ti-52\% Al alloy, as shown in Fig. 4. In two phase alloys, the $\alpha_{2}$ phase images with brighter contrast than the $\gamma$ phase, as shown in Figs. 5 and 6 for a simple ternary Ti-44 at. \% Al-0.5\% O alloy and a more heavily alloyed Ti- -47 at. $\% \mathrm{Al}, 2 \% \mathrm{Cr}, 1.8 \% \mathrm{Nb}, 0.2 \% \mathrm{~W}, 0.15 \% \mathrm{~B}$ alloy, respectively. Another example of a more complex microstructure with a brightly-imaging phase is shown in a Ta-modified Ti- $47 \% \mathrm{Al}, 2 \% \mathrm{Cr}$, $1 \% \mathrm{Nb}, 0.8 \% \mathrm{Ta}, 0.2 \% \mathrm{~W}$ and $0.15 \% \mathrm{~B}$ alloy in Fig. 7 . From its composition (Ti- 19.5 at. \% Al, $43.1 \% \mathrm{Cr}, 1.6 \% \mathrm{Nb}, 12.2 \% \mathrm{Ta}, 2.4 \% \mathrm{~W}$ ), this precipitate was determined to be a $\mathrm{TiCr}_{2}$-based Laves phase. In addition to the $\alpha_{2}$ phase, borides were also found to image brightly in these alloys, as shown in Fig. 8. Although all borides exhibit similar bright contrast in the field ion microscope, several different types of borides including $M B, M_{2}$ and $M_{2} B$ have been identified from the compositions determined in the atom probe. An atom probe composition profile across an $\alpha_{2}-\gamma$ interface in a Ti47 at. $\% \mathrm{Al}, 2 \% \mathrm{Cr}, 1.8 \% \mathrm{Nb}, 0.2 \% \mathrm{~W}, 0.15 \% \mathrm{~B}$ alloy is shown in Fig. 9 . In this example, the oxygen partitioning between the $\alpha_{2}$ and $\gamma$ phases is clearly evident. However, no segregation of $\mathrm{Cr}$ or $\mathrm{Nb}$ to the interface was observed. The results presented in this paper illustrate that titanium aluminides can be examined routinely by atom probe field ion microscopy. ${ }^{3}$

1. S. C. Huang, Structural Intermetallics, ed. R. Darolia, et al., TMS, Warrendale, PA, 1993, p. 299. 2. M. K. Miller et al., Atom Probe Field Ion Microscopy, Oxford, Oxford University Press (1996). 3. This research was sponsored by the Division of Materials Sciences, U.S. Department of Energy, under contract DE-AC05-96OR22464 with Lockheed Martin Energy Research Corp., through the SHaRE Program under contract DE-AC05-76OR00033 with Oak Ridge Associated Universities, and by an appointment (DJL) to the ORNL Postdoctoral Research Associates Program administered jointly by the Oak Ridge Institute for Science and Education and ORNL. This research was conducted utilizing the Shared Research Equipment (SHaRE) User Program facilities at ORNL.

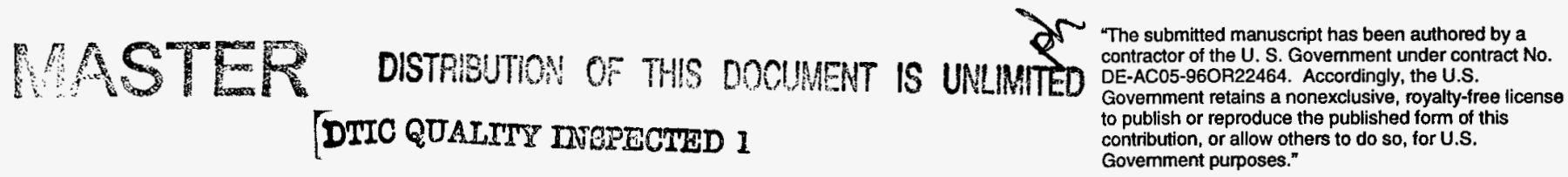




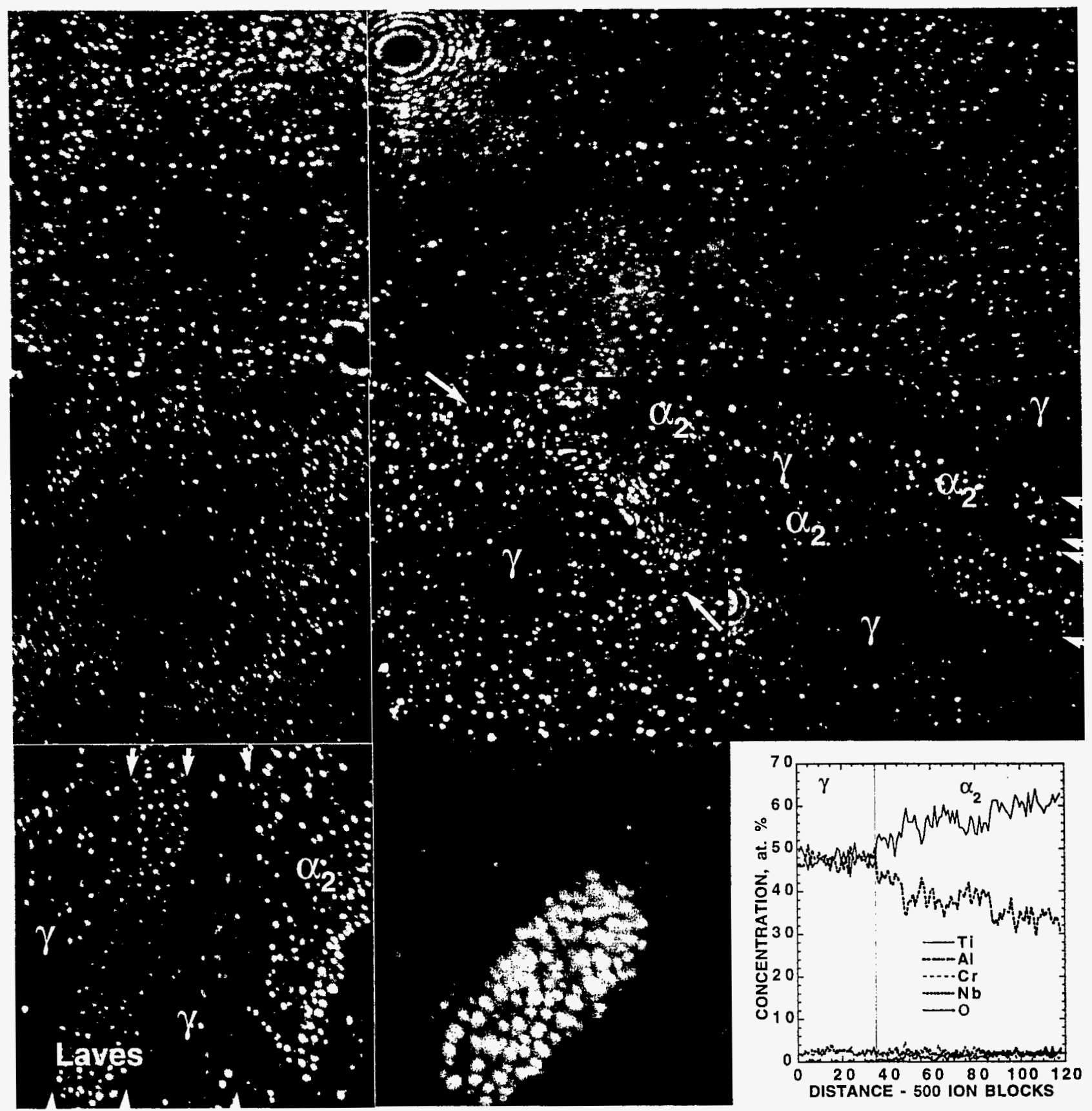

Fig. 1 Field ion micrograph of a stoichiometric $\mathrm{Ti}_{3} \mathrm{Al}\left(\alpha_{2}\right)$ alloy.

Fig. 2 Field ion micrograph of a Ti-44 at. $\%$ Al- $0.4 \% \mathrm{~B}$ alloy that was processed to retain the $\alpha$ phase. Fig. 3 Field ion micrograph of a single $\alpha_{2}$ phase Ti-20 at. \% Al-10\% Zr ternary alloy.

Fig. 4 Field ion micrograph of the $\gamma$ phase in a single phase Ti-52\% Al alloy.

Fig. 5 Field ion micrograph of $\alpha_{2}$ (bright contrast) and $\gamma$ phases in a Ti-44\% $\mathrm{Al}-0.5 \% \mathrm{O}$ alloy.

Fig. 6 Field ion micrograph of two $\alpha_{2}$ lamellae and $\gamma$ matrix in a Ti-47\% Al, $2 \% \mathrm{Cr}, 1.8 \% \mathrm{Nb}, 0.2 \%$ $\mathrm{W}, 0.15 \% \mathrm{~B}$ alloy aged for 30 days at $800^{\circ} \mathrm{C}$.

Fig. 7 Field ion micrograph of a $\mathrm{TiCr}_{2}$-based Laves phase plate, an $\alpha_{2}$ lamella and $\gamma$ matrix in a Tamodified $\mathrm{Ti}-47 \% \mathrm{Al}, 2 \% \mathrm{Cr}, 1 \% \mathrm{Nb}, 0.8 \% \mathrm{Ta}, 0.2 \% \mathrm{~W}$ and $0.15 \% \mathrm{~B}$ alloy.

Fig. 8 Field ion micrograph of a boride precipitate in the Ta-modified alloy.

Fig. 9 Atom probe composition profile from the $\gamma$ phase into the $\alpha_{2}$ phase in a $\mathrm{Ti}-47 \% \mathrm{Al}, 2 \% \mathrm{Cr}$, $1.8 \% \mathrm{Nb}, 0.2 \% \mathrm{~W}, 0.15 \% \mathrm{~B}$ alloy aged for 30 days at $800^{\circ} \mathrm{C}$. 


\section{DISCLAIMER}

This report was prepared as an account of work sponsored by an agency of the United States Government. Neither the United States Government nor any agency thereof, nor any of their employees, makes any warranty, express or implied, or assumes any legal liability or responsibility for the accuracy, completeness, or usefulness of any information, apparatus, product, or process disclosed, or represents that its use would not infringe privately owned rights. Reference herein to any specific commercial product, process, or service by trade name, trademark, manufacturer, or otherwise does not necessarily constitute or imply its endorsement, recommendation, or favoring by the United States Government or any agency thereof. The views and opinions of authors expressed herein do not necessarily state or reflect those of the United States Government or any agency thereof. 


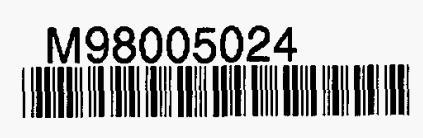

Report Number (14) ORNL/CP-96540

$\begin{array}{ll}\text { Publ. Date (11) } \frac{199801}{\text { Sponsor Code (18) }} & \frac{1 E R, X F}{U C-400, D O E / E R} \\ \text { UC Category (19) }\end{array}$ 